УДК 929:94](477.46)

DOI https://doi.org/10.32838/2663-5984/2021/4.4

\title{
Волошин I.B.
}

Черкаський інститут пожежної безпеки імені Героїв Чорнобиля Національного університету цивільного захисту України

\section{МИКОЛА ТКАЧЕНКО - ЗАБУТИЙ УКРАЇНСЬКИЙ ІСТОРИК, АРХЕОГРАФ, ШЕВЧЕНКОЗНАВЕЦЬ}

У статті досліджено суспільно-політичний портрет М.М. Ткаченка (1893-1965) у контексті украӥнського начіонального руху й украӥнської науки. Микола Михайлович Ткаченко походив із селянської родини, яка мешкала в м. Тальному, що на Черкащині. Він був унікальною людиною своєї епохи: за фахом історик, проте був і літератором (шевченкознавием), й археографом, і музеєзнавием тощо. Належав до київської історичної иколи М. Грушевського. 3'ясовано, шо саме причетність до школи М. Грушевського призвела до трагічних наслідків у житті М.М. Ткаченка: переслідування, невизнання, поневіряння й загалом забуття. Документи свідчать, що інтерес до української історії проявився в майбутнього вченого ще в середній школі, який поширюється та поглиблюється у вищій школі. Підкреслено, що великий вплив на Миколу як майбутнього науковия справив професор В. Данилевич. Доведено, щьо фактично з перших днів створення Української академії наук Микола Михайлович Ткаченко стає ї̈ співробітником, перебуваючи на різних посадах. 1927 р. М. Ткаченко поступово знайомиться зі «сталінським правосуддям». Проти науковия була сфабрикована бездоказова, абсурдна справа. Вирок - позбавлення волі на вісім місячів. Звільнившись із-під арешту, М.М. Ткаченко при повній підтримиі М. Грушевського повертається до прачі в НДКІУ без усяких перешкод. 1933 р. М.М. Ткаченка було звільнено з ВУАН «як класового ворога». Захист кандидатської дисертаиії «Історико-географічні відомості про місия перебування Т.Г. Шевченка на Україні», над якою вчений прачював тривалий час, відбувся в 1942 p. 31947 р. був змушений праиювати в Інституті історії та теорії архітектури, де стає членом Комісії для вивчення міст УРСР. У 1952-1963 рр. працюе в Інституті літератури АН УРСР. 1964 p. відбувся довгоочікуваний захист докторської дисертаиї «Начерки з історії селян на Лівобережній Украӥні». Доля М.М. Ткаченка доводить, що украӥнська історична наука 20-60-х рр. ХХ ст. розвивалася саме завдяки самовідданій прачі таких людей, як М.М. Ткаченко. Водночас його життєвий шлях, діяльність $і$ наукова спадщина потребують подальшого широкого й трунтовного дослідження.

Ключові слова: науково-дослідна кафедра історії Украӥни, М. Грушевський, Всеукраӥнська академія наук (Наиіональна академія наук України), «сталінське правосуддя», Археографічна комісія ВУАН.

Постановка проблеми. Останнім часом усе частіше в українській історичній науці вчені звертаються до персоналістичних досліджень. Актуальність таких студій зумовлена тривалим пануванням «безособової» комуністичної ідеології, за якої лише клас визнавався рушієм істоpiï. Не потребує спеціального пояснення, що українських діячів прирікали на забуття саме 3 тієї причини, що вони були справжніми особистостями свого часу. Про таку забуту постать наше дослідження.

Уродженець Черкащини та учень школи М.С. Грушевського Микола Михайлович Ткаченко (4 січня 1893 р. - 7 листопада 1965 р.) - постать мало знана серед дослідників. Однак його життєвий шлях, громадська позиція, наукова спад- щина заслуговують на особливу увагу прийдешніх поколінь, адже М.М. Ткаченко - унікальна людина своєї епохи. За фахом він був істориком, проте був і літератором (шевченкознавцем), й археографом, і музеєзнавцем тощо. Але, на жаль, найболючішим і наскрізним фактом його життя була причетність до школи М. Грушевського, а отже, переслідування, невизнання, поневіряння й загалом забуття.

Аналіз останніх досліджень і публікацій. Серед джерел, які дають змогу комплексно висвітлювати біографію діяча, треба назвати передусім праці М.М. Ткаченка. Певний об'єм біографічної та дослідницької інформації науковця знаходимо в архівних фондах України, а саме: Державному архіві Черкаської області, 
Центральному державному архіві громадських об'єднань України, Центральному державному архіві-музеї літератури та мистецтва України, Інституті рукописів Національної бібліотеки України ім. Вернадського. Тут, зокрема, є спогади, щоденники та листування, які висвітлюють внутрішній світ історика, його взаємини 3 іншими людьми тощо; матеріали діяльності наукових установ, у яких працював і 3 якими контактував учений. Автор користувався й опублікованими документами $[4 ; 5 ; 11]$.

Сучасна історіографія роботи, на жаль, дуже вузька. Загалом інформація, що міститься в радянській літературі, $є$ вузькопрофільною, викладеною за стандартними радянськими поглядами. Історики-емігранти окремої уваги М.М. Ткаченку не приділяли. Його постать і частково наукова діяльність розглядалася в контексті Київської школи М. Грушевського. У період незалежності почали 3'являтися перші наукові дослідження, присвячені життєдіяльності М.М. Ткаченка, які щонайбільше обмежуються невеличкою студією, в інших же матеріалах знаходимо поодинокі згадки про вченого $[1 ; 3 ; 6 ; 8 ; 9 ; 13-15]$.

Постановка завдання. Метою дослідження $€$ охарактеризувати основні віхи життєвого шляху й діяльності Миколи Михайловича Ткаченка в контексті українського національного руху й української науки. Зауважимо, що ми спробуємо подати лише деякі сюжети із життя та наукового доробку M.М. Ткаченка, адже весь його суспільно-політичний і науковий портрет, на наш погляд, потребує спеціального й грунтовного, навіть монографічного дослідження.

Виклад основного матеріалу дослідження. Народився Микола Михайлович Ткаченко 04.01 .1893 (23.12.1892 за ст. ст.) у м. Тальному на Уманщині (нині Звенигородській район Черкаської області) у селянській православній сім'ї [7, 118 зв.-119 арк.]. Батько - селянин із м. Шполи Михайло Іванович, мати - Валентина Григорівна. Серед чотирьох дітей Микола був найстаршим у сім'ї.

Про дитячі роки Миколи Михайловича відомостей дуже мало. У 1902-1911 pр. він уже навчався в Київській 2-й гімназії [1, с. 127]. «Інтерес до історичних наук утворився у мене за часів перебування у середній школі», - писав Ткаченко 11.05.1927 в автобіографії. Після школи одразу вступив на історико-філологічний факультет Київського університету, який закінчив у 1916 р. 3 «Диплома М. Ткаченка про закінчення Університету Св. Володимира» дізнаємося, що навчався він на історичному відділенні історикофілологічного факультету У вищій школі інтерес до української історії поширюється та поглиблюється, що пов'язано з практичними заняттями 3 давньої української історії під керівництвом професора В. Данилевича. Результатом стає написана під керівництвом згаданого професора курсова робота «Канівська сотня Переяславського полку за Рум'янцевської ревізії», яку потім було зараховано за дипломну. 29.11.1916 Микола Михайлович Ткаченко був удостоєний диплома Першого ступеня [1, с. 116].

Саме в університеті Микола Михайлович сформувався як особистість, патріот України; окрім того, він мав непересічні наукові здібності. Навчаючись в університеті, Микола активно займається громадською діяльністю.

По закінченні університету він отримав посаду вчителя гімназії. Згодом, коли вже за Радянської влади гімназії перетворилися в народні школи, працював учителем кількох шкіл. Невдовзі здібного педагога призначили завідувачем однієї 3 трудових шкіл, інструктором у шкільній секції губнаросвіти [12, арк. 24-24 зв.].

Певний час Микола Михайлович працював помічником бібліотекаря в історичному кабінеті ВIHО (Вищий інститут народної освіти у Києві, сьогодні - Київський національний педагогічний університет ім. М. Драгоманова). Тут мав приязні стосунки з Ольгою Грушевською (дружиною Олександра Грушевського), що стало приводом до подальшої співпраці з родиною Грушевських.

31919 р. М.М. Ткаченко стає постійним співробітником Історико-географічної комісії О. Грушевського, а 31923 р. - іiі секретарем [12, арк. 24-24 зв.].

Таким чином, фактично з перших днів створення Української академії наук Микола Ткаченко був її співробітником, перебував на таких посадах: співробітник Комісії для складання історикогеографічного словника української землі, керівник Комісії Полудневої України, співробітник постійної Комісії для складання словника живої української мови при Історико-філологічному відділі, співробітник Археографічної комісії.

«У 1921 або 1922 р. я поступив асистентом Катедри історії України при ВIHО», - згадував М. Ткаченко [12, арк. 24 зв.]. У 1924-1927 pр. він аспірант, скарбник історичної секції, нештатний постійний співробітник Комісії Степової України та Чорномор'я, виконувач обов'язки керівничого Комісії Полудневої України (1925-1927рр.), член-співробітник географічної секції природни- 
чого відділу Інституту української наукової мови (1926 р.), голова Комісії Степової України історичної секції (1926 р., 1927 р.) і секретар Комісії для досліду території Дніпрельстану (1927р.); штатний співробітник кафедри історії України (1927-1928 рр.), член Комісії для дослідження нової української історіографії (1928р.).

Ще одним підтвердженням активної участі M.М. Ткаченка в роботі Історичної секції $\epsilon$ подання ним за 1921-1924 рр. до цієї установи 11 рефератів. Його колеги ж по секції подали по 3-4 реферати [15, с. 144]. Таким чином, Микола Михайлович зумів показати себе з кращого боку, що дало змогу й надалі бути членом НДКІУ.

29 травня 1924 р. М.С. Грушевський звернувся 3 листом до київського уповноваженого наукового комітету НКО УСРР, де просить затвердити M.М. Ткаченка разом $з$ іншими істориками аспірантами НДКІУ, які «могли б з користю зараз же почати заняття» $[15$, с. 49$]$.

15 червня 1926 р. відбулася промоція аспіранта Миколи Михайловича Ткаченка. Як зазначено в «Особистій карточці аспіранта, зареєстрованого Укрнаукою» від 28.03.1927, М.М. Ткаченко читав, писав німецькою, французькою, польською, латинською, грецькою мовами, цілком володів російською та українською [1, с. 121-122].

М.С. Грушевський клопотався про збільшення штатів НДКІУ, це стосувалося й М.М. Ткаченка. Під кінець 1926 р. М.М. Ткаченко був висунутий науковим співробітником катедри, де й почав проходити випробувальний етап.

31927 p. М.М. Ткаченко поступово знайомиться зі «сталінським правосуддям». Головна причина - прямий стосунок до родини Грушевських і занадто активна громадянська позиція. 06.06.1927 покінчив життя самогубством відомий мистецтвознавець і музейний працівник України Д.М. Щербаківський, із яким М.М. Ткаченко був у добрих стосунках. Відтак останній став одним із ініціаторів написання листа групи вчених Києва до редакції газети «Пролетарська правда» 3 приводу цієї трагедії, на що Нарком освіти України М.О. Скрипник у виступі в липні 1927 р. на пленумі Центрального бюро секції наукових співробітників УСРР звинуватив авторів «Листа до Редакції» у спробах використання смерті Д.М. Щербаківського з метою політичних маніпуляцій академічних кіл проти радянської влади.

Усе продовжилося 1928 р. Так, 05.03.1928 співробітником ДПУ на квартирі історика по вулиці Леніна, 74 відбувся обшук, після чого в окружний відділ ДПУ були доставлені речові докази: особисте листування, 8 використаних фотопластинок і 10 географічних карт на м'якому папері [12, арк. 15]. М.М. Ткаченка було затримано. Це був перший арешт співробітника НДКІУ. 19.03.1928 йому було висунуто звинувачення в злочинах, передбачених ст. ст. 5410, 5411 Кримінального кодексу УСРР, що полягали в «преступной деятельности, выражавшейся в проведении контрреволюционной деятельности, активизации и пропаганде» [12, арк. 6], у проведенні «протирадянської агітації і пропаганди і спроби створити контрреволюційну організацію». «Контрреволюційна» діяльність убачалася в проведенні «мілітаризації вищих учбових закладів та здійсненні радіовибуху». Нібито передбачалося створення Військово-наукового товариства, до якого М.М. Ткаченко мав провести своїх людей, у якому мав зайняти керівні позиції й проводити там «шовіністичну роботу». I хоча в матеріалах слідства визнано, що «відділень Військово-наукового товариства, на які Ткаченко звернув увагу, ще не було зовсім, і сама робота по захвату військової справи була тільки в проекті», цього було достатньо, щоб розпочати кримінальну справу. Як зазначалося в матеріалах слідства, для здійснення поставленої мети необхідно було «дістати тисяч двадцять-тридцять рублів, потратити на справу півтора-два роки, завоювати довіру у вищих радянських та партійних сферах, щоб потім у приміщенні будь-якого вищого радянського чи партійного органу поставити радіоапарат із зарядом хвилі певної довжини, а потім, скажімо, на річний з'їзд партії, знаходячись де-небудь на площі, включити в кишеньковий радіоприймач необхідну хвилю і таким чином викликати вибух у приміщенні» [12, арк. 60]. Як уважає О. Федірко, слідча справа М.М. Ткаченка була скомплектована малограмотно й повна протиріч. Абсурдність формулювання видно з того, що «заряд хвилі певної довжини» $€$ фізичним нонсенсом, безглуздим набором фізичних термінів, не пов'язаних один із одним [13, с. 471$]$.

Протягом трьох непростих допитів науковець вдало доводив свою непричетність до висунутих проти нього звинувачень. Одного разу слідчий навіть пригадав йому випадок із листом групи вчених з приводу трагічної смерті Д.М. Щербаківського. Усе ж М.М. Ткаченко стояв на своєму, на що слідчий у звинувачувальному висновку зазначав, що М.М. Ткаченко - повністю радянська людина, яка ні в чому не має розходжень із радянською владою, іiі принципами й політикою, про план радіовибуху він нічого не знає, узагалі 
про радіо як про досягнення техніки знає дуже поверхово, ніякої літератури із цього питання не читав і спеціально цим питанням ніколи не цікавився [12, арк. 62]. Але цілком спростувати звинувачення не вдалося. «Агентурного матеріалу» було достатньо для того, щоб 25.04.1928 Київський окружний відділ ДПУ визнав М. Ткаченка «антирадянським елементом» i вимагав його ув'язнення терміном на три роки [12, арк. 73]. Справу було направлено на розгляд до Особливої Наради при Колегії ОДПУ. 3 діагнозом «неврастенія» М.М. Ткаченко був переведений до Москви.

Усе ж після довгої тяганини 08.10.1928 постановили: «Ткаченко Николая Михайловича приговорить к лишению свободы сроком на 8 мес. считая срок с 6.03.1928» [12, арк. 69-70]. Більшменш вдале завершення справи все одно вплинуло на моральне, психологічне та фізичне здоров'я науковця.

Виникає слушне запитання: як керівник НДКІУ М.С. Грушевський відреагував на цю ситуацію? На думку О. Юркової, до своїх співробітників по НДКІУ М.С. Грушевський ставився надзвичайно уважно. Звільнившись із-під арешту М.М. Ткаченко повернувся до праці в НДКІУ без усяких перешкод. I вже на початку 1929 р. М.С. Грушевський ставить перед Укрнаукою питання про поновлення його підопічному платні. Більше того, на кафедрі невдовзі відбуваються вибори нового секретаря, і прізвище науковця фігурує як одна 3 двох кандидатур. О. Юркова припускає, та й ми iii цілком підтримуємо, що таким чином М. Грушевський доводив свою довіру до колишнього в'язня й демонстрував, що вважає арешт Миколи Михайловича Ткаченка безпідставним. Крім того, цей вчинок промовляє також про сміливість і неупередженість академіка [15, с. 108].

У 1929 р. історик увійшов до складу Комісії для виучування соціально-економічної істоpiï України XVIII-XIX ст. Праця в цій Комісії M.M. Ткаченка була невипадковою, адже одним iз напрямів історичних досліджень ученого стала саме соціально-економічна історія Лівобережної України XVII-XVIII ст.

У травні 1931 р., будучи призначеним керівником Археографічної комісії ВУАН, М.М. Ткаченко номінально залишив штатну посаду в Історичногеографічній комісії. Утім, бажаючи завершити розпочаті раніше численні студії з історичної географії України, М.М. Ткаченко просив дозволу в Президії II Відділу ВУАН продовжувати працю в Історично-географічній комісії «у вільний час від безпосередньої роботи по Археографічній комі- сії». I хоча таку працю історик у 1931-1933 pp. справді проводив, до іiі завершення справа не дійшла, як, зрештою, не була поцінована праця науковця як керівничого Археографічної комісії в часи постійних перевірок, чисток, критики: у серпні 1933 р. М.М. Ткаченка було звільнено 3 ВУАН «як класового ворога» (це сина селянина!) $[15$, с. 256$]$. Цього ж року з'являються статті, у яких діяльність дослідника була піддана цькуванню. До 1933 р. М. Ткаченко був членом Всеукраїнського археографічного комітету, який теж потрапив у комплекс нищення наукових цінностей, переслідування археологічних установ.

Суспільствознавця було відлучено від Академії, але не від науки. Трохи змінивши фах, у 1934-1940 рр. він викладав географію в школі для дорослих у м. Києві. У період викладання в школі, будучи відлученим від Академії, M.М. Ткаченко залишався під пильним наглядом органів безпеки.

У 1941 р. вчений був евакуйований до Харкова, а згодом до Уфи. У столиці Башкирії вчений стає науковим співробітником об'єднаного Інституту історії та археології. У 1942-1943 навчальному році М. Ткаченко читав на III курсі історичного факультету лекції з російської історіографії [2, арк. 4]. У 1942 р. історик захистив кандидатську дисертацію «Історико-географічні відомості про місця перебування Т.Г. Шевченка на Україні», над якою працював тривалий час, проте захист роботи щоразу відтягувався (схоже на почерк радянської влади).

Після повернення у визволений Київ М.М. Ткаченко й інші співробітники Інституту займалися збиранням і науковою обробкою матеріалу з історії німецько-радянської війни. Із цією метою їх було відряджено на фронт із збиральницькими бригадами. В Інституті історії вчений виконував велику частину роботи. Незважаючи на це, у січні 1947 р. за наказом директора Інституту М.Н. Петровського його було звільнено з Інституту, мовляв, за «хронічне невиконання планів у 1942-1946 рр.». М.М. Ткаченко апелював до різних установ, але поновлення на посаді він не домігся й змушений був влаштуватися на роботу до Інституту історії та теорії архітектури. Незважаючи на зазначену ситуацію, з науковцем рахувалися. Так, бюро Відділу суспільних наук АН УРСР на засіданні 11.05.1949 ухвалило утворити Комісію для вивчення міст УРСР. Старший науковий співробітник Академії архітектури М.М. Ткаченко був запрошений для роботи в цій Комісії, а 03.06.1949 його обрали її членом. 
31952 р. історик знову повертається до Інституту літератури АН УРСР, де працював до березня 1963 р. Тут Миколі Михайловичу Ткаченку дали планову тему «Основні дати життя й творчості Т.Г. Шевченка».

В останні роки життя М.М. Ткаченко отримав ще кілька наукових призначень. Так, у 1958 р. він став членом наукової ради при Архівному управлінні УРСР, 16 червня 1961 р. при Інституті історії АН УРСР була створена рада 3 проблем «Історії історичної науки на Україні», членом Наукової ради з проблем якої був затверджений і Микола Михайлович Ткаченко [2, арк. 2].

16.01.1964 відбувся довгоочікуваний захист докторської дисертації М.М. Ткаченка. Учений ішов до нього понад 20 років, саме стільки «Начерки з історії селян на Лівобережній Україні» пробивали собі шлях до офіційного визнання [15, с. 258]. Прикметно, що тема докторської продовжила його наукові студії, початі М.С. Грушевським. Спроби захисту дисертації мали місце ще в 1952 р. та 1954 р. Рецензію на неї дав І.П. Крип'якевич. Та навіть перед захистом дисертації виникло непорозуміння: М.М. Ткаченка було за віком скорочено з Інституту літератури, хоч люди пенсійного віку працювали в різних Інститутах $\mathrm{AH}$, тому постала проблема захисту дисертації.

Ми неодноразово відмічали про різне, не завжди приязне ставлення до М.М. Ткаченка. Усе ж 04.01.1963 він отримав Вітальний адрес Інституту історії АН УРСР з нагоди 70-річчя від дня свого народження (можливо, і формально). У привітанні йде мова про заслуги М.М. Ткаченка:
«За цей час Ви написали багато важливих досліджень з історії України. Ваші монографії і нариси з історії міст і селян України XVII-XVIII ст., біографічні та інші дослідження, написані на підставі великого фактичного матеріалу, знайшли широке коло читачів-науковців, викладачів вузів і шкіл, працівників музеїв, архіві, студентів. Своїми працями Ви внесли значний вклад в розвиток нашої радянської історичної науки» [2, арк. 2].

Щодо сім'і, то відомо лише те, що до війни М.М. Ткаченко був одружений з археологом Валерією Козловською, яка виїхала на Захід. Його другою дружиною стала колишня співробітниця Всенародної бібліотеки України Єфросинія Плескач. На цей момент нам поки що невідомо, чи були в М.М. Ткаченка діти.

07.11.1965 Микола Михайлович Ткаченко помер. Радянський режим робив усе можливе для того, щоб постать М.М. Ткаченка залишилася забутою. Але для сучасної історичної науки та української історіографії його ім'я вже не $\epsilon$ втраченим, а наукова спадщина стає предметом дослідницьких студіювань.

Висновки. У підсумку зауважмо на кількох моментах: 1) Микола Михайлович Ткаченко-забутий український історик, археограф, шевченкознавець, член Всеукраїнської академії наук, учень школи М. Грушевського, постать із трагічною долею; 2) українська історична наука 20-60-х рр. XX ст. розвивалася саме завдяки самовідданій праці таких людей, як М.М. Ткаченко; 3) життєвий шлях, діяльність і наукова спадщина вченого потребують подальшого широкого й грунтовного дослідження.

\section{Список літератури:}

1. Білокінь С.І. Київська школа акад. М. Грушевского. УІЖ. 1996. № 5. С. 106-130.

2. Вітальний адрес Інституту історії АН УРСР з нагоди 70-річчя від дня народження. 04.01.1963. Центральний державний архів-музей літератури та мистецтв Украӥни. Ф. 256. Оп. 1. Спр. 60.

3. Заруба В. Знищення київської школи істориків М. Грушевського (1929-1934рр.). Збірник наукових праць і матеріалів Міжнародної ювілейної конференції, присвяченої 125-й річниці від дня народження Михайло Грушевський. Львів : НТШ у Львові, 1994. С. 403-411.

4. Історія Академії наук України. 1918-1923: Документи і матеріали / упоряд. В.Т. Шмельов та ін. Київ, $1993.376 \mathrm{c}$.

5. Історія НАН України. 1924-28. Документи і матеріали / упоряд. В.А. Кучмаренко та інші. Київ : НБУВ, 1998. $764 \mathrm{c.}$

6. Масненко В.В. Микола Ткаченко як дослідник життя і творчості Тараса Шевченка. Тарас Шевченко i народна культура : збірник праць міжнар. 35-ї наук. Конференції : у 2 кн. Черкаси : Брама-Україна, 2004. Кн. 2. С. 323-337.

7. Метричная книга родившихся 1882-1904 гг. Троицкая церковь г. Тального, 4 округа, Уманського уезда, Киевской губернии. Державний архів Черкаської області. Ф. 931. Оп. 1. Спр. 2420.

8. Мицик Ю. Умань козацька і гайдамацька. Київ : Вид. дім «КМ Академія», 2002. 187 с.

9. Ніколенко Ю. М.М. Ткаченко - дослідник історії козацтва. Нові дослідження пам'яток козащької доби в Украӥні : збірник наук. статей. Київ : ХІК, Часи козацькі, 2005. Вип. 14. С. 371-374.

10. Сороковська С.В. Українська радянська історична бібліографія. Київ, 1980. 124 с. 
11. Уголовное дело № 59296 по обвинению Плевако А.А. и Ткаченко Н.М. (12.03.1928-25.04.1928). Центральний державний архів громадських об'єднань України. Ф. 263. Оп. 1. Спр. 69709. Т. 1.

12. Уголовное дело № 59296 по обвинению Плевако А.А. и Ткаченко Н.М. (12.03.1928-25.04.1928). Центральний державний архів громадських об’єднань України. Ф. 263. Спр. 69709. Т. 1.

13. Федірко О.А. Микола Михайлович Ткаченко. Зневажена Кліо. Київ, 2005. С. 467-480.

14. Юркова О. Київська історична школа М.С.Грушевського: долі науковців. 3 архівів ВУЧК, ГПУ, НКВД, КГБ. 1998. № 1/2 (6/7). С. 263-413.

15. Юркова О.В. Діяльність Науково-дослідної кафедри історії України М.С. Грушевського (1924-1930рр.). Київ, 1999. 433 с.

\section{Voloshyn I.V. MYKOLA TKACHENKO - FORGOTTEN UKRAINIAN HISTORIAN, ARCHAEOGRAPHER, SHEVCHENKO SCHOLAR}

The article examines the socio-political portrait of M.M. Tkachenko (1893-1965) in the context of the Ukrainian national movement and Ukrainian science. Mykola Mykhailovych Tkachenko came from a peasant family that lived in the town of Talne in Cherkasy region. He was a unique man of his time: a historian by profession, he was also a writer (Shevchenko scholar), an archaeographer, a museologist, and so on. He belonged to the Kyiv historical school of M. Hrushevsky. It is found out that it was involvement in the school of M. Hrushevsky that led to tragic consequences in the life of M.M. Tkachenko: persecution, nonrecognition, wandering and in general - oblivion. Documents show that the future scientist became interested in Ukrainian history in secondary school, which was spreading and deepening in high school. It is emphasized that professor V. Danylevych had a great influence on Mykola as a future scientist. It is proved that in fact from the first days of the Ukrainian Academy of Sciences Mykola Tkachenko became its employee, holding various positions. In 1927, M. Tkachenko gradually became acquainted with "Stalin's justice". An unproven, absurd case was fabricated against the scientist. The sentence was imprisonment for eight months. After being released from custody, M.M. Tkachenko, with the full support of M. Hrushevsky, returned to work at the Research Department of History of Ukraine at the All-Ukrainian Academy of Sciences without any obstacles. In 1933, M.M. Tkachenko was released from the All-Ukrainian Academy of Sciences "as a class enemy". The defense of the candidate's dissertation "Historical and geographical information about the whereabouts of Taras Shevchenko in Ukraine", on which the scientist worked for a long time, took place in 1942. From 1947 he was forced to work at the Institute of History and Theory of Architecture, where he became a member of the Commission to study the cities of the Ukrainian SSR. From 1952 to 1963 he worked at the Institute of Literature of the Ukrainian Academy of Sciences. In 1964 the long-awaited defense of the doctoral dissertation "Essays on the history of peasants in the Left Bank of Ukraine" took place. The fate of M.M. Tkachenko proves that the Ukrainian historical science of the 20-60s of the twentieth century developed precisely due to the selfless work of people like M. Tkachenko. At the same time, his way of life, activities and scientific heritage need further extensive and thorough research.

Key words: Research Department of History of Ukraine, M. Hrushevsky, All-Ukrainian Academy of Sciences (National Academy of Sciences of Ukraine), "Stalin's justice", Archaeological Commission of the All-Ukrainian Academy of Sciences. 